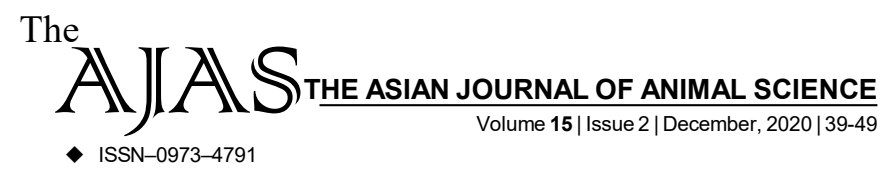

\title{
A study of bacterial qualities of raw milk of cow and goat
}

\section{U.K. Shukla, Abhishek Thakre and Shri Kant}

Author for Corresponding -

\section{Shri Kant}

Livestock Production and Management Unit, Department of Natural Resource

Management, Faculty of Agriculture, Mahatma Gandhi Chitrakoot Gramodaya Vishwavidyalaya, Chitrakoot, Satna (M.P.) India Email: shrikantag695@gmail. com
ABSTRACT...... A comparative study of chemical qualities of raw milk of cow and goat was conducted at Livestock production and management (unit), Department of NRM, faculty of agriculture, MGCGV Chitrakoot - Satna (M.P.) during January, 2020. The objective was to find out the comparative chemical qualities of raw milk of cow and goat for three animal each viz., cow and goat for ten days as replication different parameter were subject to statistical analysis applying the technique of analysis of variance (f-test) the most widely used method for determining protein content by kjeldahi method for nitrogen determination since nitrogen is a characteristic can be finding. In view of the finding and results presented above, it may be concluded that the chemical quality of milk of cow was superior than goat milk, due to higher protein, specific gravity, fat content, lactose, total solid and solid not fat and lower ash and water content in cow milk.

KEY WORDS...... Raw milk, Chemical quality, Cow, Goat

HOW TO CITE THIS ARTICLE - Shukla, U.K., Thakre, Abhishek and Kant, Shri (2020). A study of bacterial qualities of raw milk of cow and goat. Asian J. Animal Sci., 15(1): 39-49.DOI:10.15740/HAS/ TAJAS/15.2/39-49.Copyright@2020:HindAgri-Horticultural Society.

ARTICLE CHRONICLE - Received : 11.06.2020; Revised : 05.10.2020; Accepted : 02.11.2020 